\title{
Middle Weichselian environments on western Yamal Peninsula, Kara Sea based on pollen records
}

\author{
Andrei A. Andreev ${ }^{\mathrm{a}, *}$, Steven L. Forman ${ }^{\mathrm{b}}$, Ólafur Ingólfsson ${ }^{\mathrm{c}}$, William F. Manley ${ }^{\mathrm{d}}$ \\ a Alfred Wegener Institute for Polar and Marine Research, Research Unit Potsdam, Telegrafenberg A43, 14473 Potsdam, Germany \\ ${ }^{\mathrm{b}}$ Department of Geological Sciences, University of Illinois at Chicago, Chicago, IL 60607, USA \\ ${ }^{\mathrm{c}}$ Department of Geology and Geography, University of Iceland, Is-101 Reykjavik, Iceland \\ ' Institute of Arctic and Alpine Research, University of Colorado, Boulder, CO 80309, USA
}

Received 9 April 2004

Available online 2 February 2006

\begin{abstract}
Pollen data from two sections from a coastal cliff on the western Yamal Peninsula $\left(69^{\circ} 43.27^{\prime} \mathrm{N}, 66^{\circ} 48.80^{\prime} \mathrm{E}\right)$ document the environmental history during the Karginsky (Middle Weichselian) interstadial. Low pollen concentrations, high amounts of redeposited pollen, and relatively high presence of Artemisia pollen characterize sediments deposited at about 33,000 ${ }^{14} \mathrm{C}$ yr B.P. Grass-sedge plant associations with few other herbs occupied the area during the late Karginsky interstadial. Artemisia pollen may indicate rather xerophytic vegetation and disturbed soils in the area. The dominance of redeposited pollen reflects scarce (disturbed) vegetation cover and low pollen productivity. The climate was relatively cold and dry. Sediments dated to $32,400{ }^{14} \mathrm{C}$ yr B.P. contain fewer redeposited pollen and concentration of non-redeposited pollen is significantly higher. Pollen contents indicate the dominance of tundra-like grass-sedge vegetation and more humid conditions. Pollen records dated between 30,100 and $25,100{ }^{14} \mathrm{C}$ yr B.P. also reflect scarce tundra-like vegetation during this interval. The presence of Betula nana and Salix pollen may reflect limited presence of shrub communities. This suggests that the climate was somewhat warmer during the latter part of the interstadial. However, generally the pollen records show that harsh environmental conditions prevailed on the Yamal Peninsula during the Karginsky interstadial.
\end{abstract}

(C) 2006 University of Washington. All rights reserved.

Keywords: Pollen; Yamal Peninsula; Arctic Siberia; Karginsky interstadial

\section{Introduction}

Little is known of past climatic and environmental fluctuations during the Karginsky (Middle Weichselian) interstadial in the Siberian Arctic. Recent field studies in the Arctic Siberia have documented restricted Middle-Late Weichselian glaciation (e.g. Möller et al., 1999; Alexanderson et al., 2001; Forman et al., 2002; Mangerud et al., 2002). However, the vegetation cover and climate during this interval are still poorly known for much of the high Arctic Eurasia. Environmental reconstructions require well-dated sediment sequences containing paleoclimatic proxy records, such as pollen and macrofossils. Currently, there are only a few century to millennialscale and well-dated paleoenvironmental records spanning the

\footnotetext{
* Corresponding author.

E-mail address: aandreev@awi-potsdam.de (A.A. Andreev).
}

past ca. $45 \mathrm{ka}$ from the Taymyr Peninsula, Laptev and EastSiberian Seas coast (Andreev et al., 2001, 2002a,b, 2003). A severe Karginsky environment has been reconstructed based on pollen records from coastal areas of the Laptev Sea (Andreev et al., 2002a; Schirrmeister et al., 2003), East-Siberian Sea (Andreev et al., 2001), Northern Taymyr (Andreev et al., 2003), and Verkhoyansk Mountains (Andreev et al., 2004). However, northern taiga or forest-tundra vegetation has been reconstructed in modern treeless areas in the southern Taymyr during the Karginsky time (Andreeva and Kind, 1982; Andreev et al., 2002b). Warm Karginsky environment is also reconstructed in the West Siberia (e.g. Arkhipov and Volkova, 1994 and references therein).

This paper presents the reconstruction of vegetation and climate changes on the western Yamal during the late Karginsky time based on two sections from a coastal cliff near the Marresale Polar Station on western Yamal Peninsula, Russia (Fig. 1). Lithostratigraphic, geochronological, and stratigraphic records 


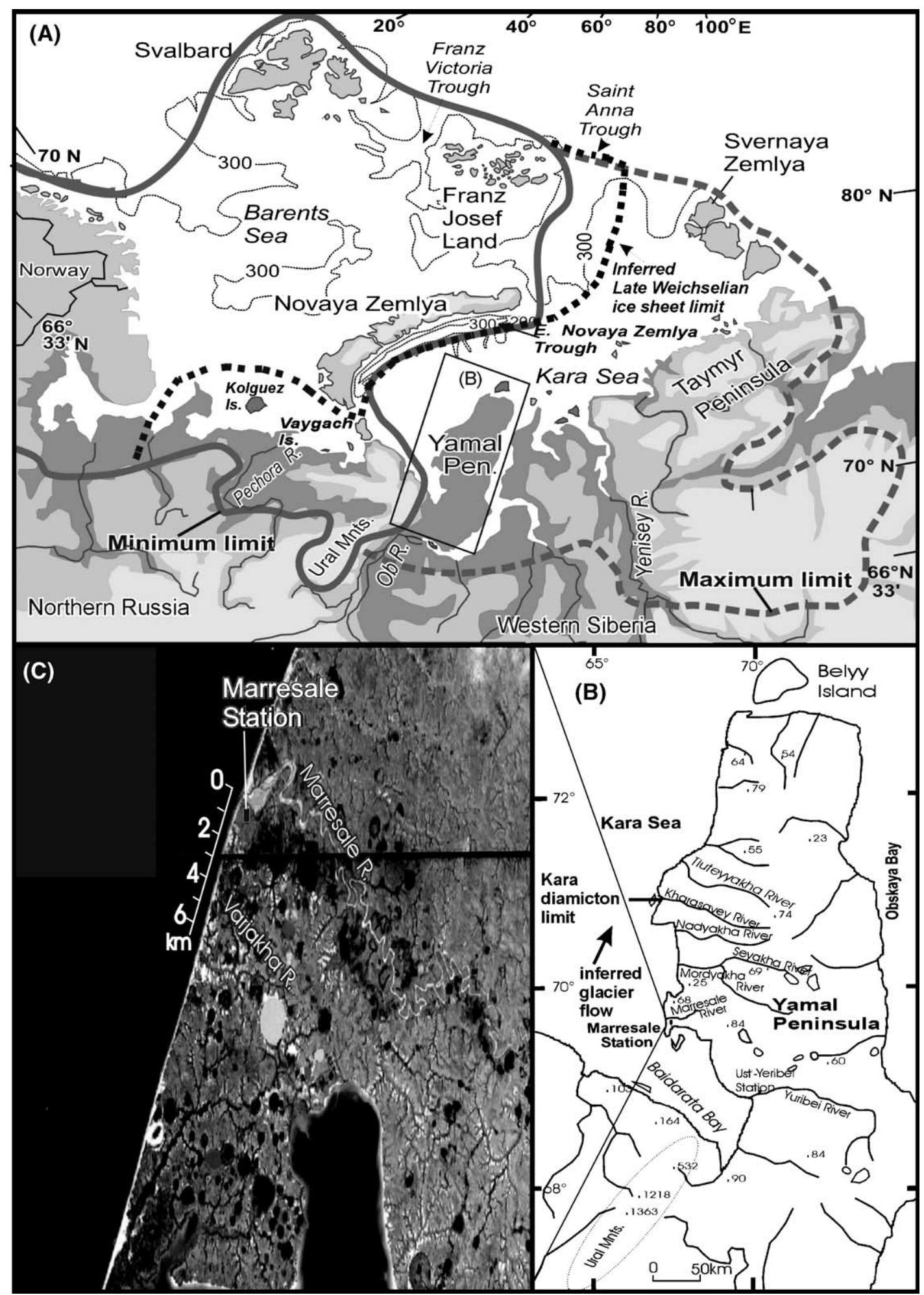

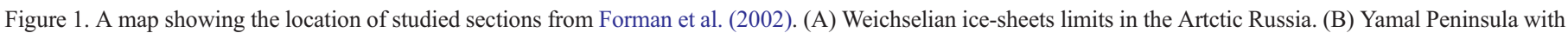
main rivers and spot elevations. (C) Corona Satellite image of Western Yamal.

are previously presented (Forman et al., 1999, 2002). This study focuses on the environmental changes reflected in the pollen records from Karginsky peaty and silty sediments (the so-called Varjakha Peat and Silt and Oleny Sand stratigraphic units according to Forman et al., 1999, 2002), with associated ${ }^{14} \mathrm{C}$ and infrared-stimulated luminescence (IRSL) dates.
Study area

Quaternary sediments, overlaying Mesozoic and Cenozoic strata, cover the Yamal Peninsula. The well-exposed coastal cliff sections of western Yamal Peninsula were investigated within $5 \mathrm{~km}$ south of the Marresale Polar Station $\left(69^{\circ} 43.27^{\prime} \mathrm{N}\right.$, 
$66^{\circ} 48.80^{\prime}$ E, Fig. 1) by Forman et al. (1999, 2002). Varjakha Peat and Silt overlies the Kara diamicton, a major till unit, in the southern part of the studied area, and is in turn overlain by the Oleny Sand (Forman et al., 1999, 2002). The locations of studied sections (so-called 4.1 and $4.7 \mathrm{~km}$ sections) were determined in kilometers measured from the south bank of the Marresale River.

The Varjakha Peat and Silt can be traced for nearly a kilometer along the coastal cliffs, as 5-20 m wide and 4-5 m deep basin infills in the underlying Kara diamicton. The sediment is thickest in basins and is characterized by subhorizontal centimeter-scale alternating beds of sandy silt and peat layers. The peat is well preserved, fibrous, and dominated by Sphagnum remains with $<20 \%$ mineralogenic component. The sandy-silt beds can contain up to $20 \%$ peat and can be traced laterally for tens of meters. The unit is a primary deposit, with no observed sediment reworking. The Oleny Sand conformably overlies the Varjakha Peat and Silt (Forman et al., 1999, 2002). It is well-sorted fine sand to fine sandy silt with $\mathrm{mm}$ - to $\mathrm{cm}$-scale subhorizontal and undulatory stratification of eolian origin. Bedding in the Oleny sand is graded, with top finer grained laminae exhibiting a diffusive lower boundary and containing in situ rooted vascular plant remains that indicate repeated brief periods of subaerial exposure and subsequent burial by eolian sand. There is no evidence of sediment reworking in the Oleny Sand.

Presently, the mean July and January temperature is about $6-8^{\circ} \mathrm{C}$ and -20 to $-22^{\circ} \mathrm{C}$, respectively in the area, with a mean annual temperature of $\sim-8^{\circ} \mathrm{C}$ (Atlas Arktiki, 1985). The total annual precipitation is $300-400 \mathrm{~mm}$. Soils in the area are tundra-gley and peaty-gley (histosols and inceptisols), characteristic of the northern tundra zone. Low shrub-herb-moss plant associations dominate the vegetation, with species such as Betula nana, Salix reptans, S. polaris, Dryas octopetala, Empetrum hermaphroditum, Vaccinium vitis-idaea, Saxifraga hirculus, Hedysarum arcticum, Carex ensifolia, Poa arctica, Nardomsia frigida and mosses such as Aulacomnium trigidum, Drepanocladus iniciatus, Calliergon sarmentosum, Hylocomium splendens (Atlas Arktiki, 1985).

\section{Field and laboratory methods}

In the field, samples were collected by first cleaning the exposure with a knife to expose frozen deposits, then cutting contiguous samples at $20-40 \mathrm{~cm}$ intervals and transferring them to sample bags. Pollen samples were prepared using slight modifications of standard techniques (Faegri et al., 1989). Modifications included: multiple treatments of boiling $\mathrm{HF}$, up to $3 \mathrm{hs}$ each, followed by rinses with warm, concentrated $\mathrm{HCl}$; three min of acetolysis; and fine-sieving of all samples with an $8 \mu \mathrm{m}$ nitex screen (Cwynar et al., 1979).

For each sample, 300-500 terrestrial pollen grains were counted at $400 \times$ magnification, and spores were tallied in addition. We assumed that Tertiary spores and indeterminable, poor-preserved Pinaceae are obviously redeposited taxa. In case when the coniferous taxa were well preserved and non- mineralized they were counted as the primary pollen, although most of them were probably also reworked from the older sediments. Such sediments accumulated during warmer interglacial(s), when the area was covered by coniferous forests inferred from studies on Yamal Peninsula (Volkova, 1999).

Determination of relative frequency of pollen is based upon the tree and herb pollen sum. The percentage of spores is based upon a sum of pollen and spores. The percentage of obviously redeposited taxa (Tertiary spores and indeterminable, poorpreserved Pinaceae) is based upon a sum of pollen and redeposited taxa. The percentage of algae is based upon a sum of pollen and algae (Berglund and Ralska-Jasiveczowa, 1986). The TILIA plotting program is used for graphing the pollen data (Grimm, 1991).

\section{Results and discussion}

The oldest Varjakha Peat and Silt sediments are presented in the 4.1-km section (Fig. 2). The pollen percentage diagram is zoned by visual inspection. Pollen zone I (PZ-I) at the 335$575 \mathrm{~cm}$ a.s.l. is notable for large amounts of reworked palynomorphs (Tertiary spores and indeterminable Pinaceae). Low pollen concentrations, high amounts of redeposited pollen, the dominance of Poaceae and Cyperaceae pollen and relatively high amounts of Artemisia pollen characterize bottom sediments, dated from $33,400 \pm 450$ to $32,400 \pm 440$ ${ }^{14} \mathrm{C}$ yr B.P. and $45,100 \pm 4000$ to $41,300 \pm 4000$ IRSL yr B.P., respectively (Forman et al., 2002). Non-linearities between the radiocarbon and calendar time scales are well documented for the past $50 \mathrm{ka}$ (Stuiver et al., 1998; Kitagawa and van der Plicht, 1998). The ${ }^{14} \mathrm{C}$ age of ca. $33 \mathrm{ka}$ corresponds approximately to corresponding calendar age of 35 to $38 \mathrm{ka}$, which overlaps with IRSL ages within two-sigma. Thus, the Varjakha Peat and Silt reflects paleoenvironmental conditions sometime between 35 and $45 \mathrm{ka}$.

The pollen spectra reflect grass-sedge vegetation with few other herb taxa occupied the area during this time, corresponding to the late Karginsky interstadial. Artemisia pollen may indicate rather xerophytic vegetation, and/or disturbed soils in the area. High amounts of poorly preserved redeposited Pinaceae pollen reflect scarce (disturbed or open) vegetation cover and/or low pollen productivity of local vegetation. The climate was relatively cold and dry.

The upper part of the 4.1 section (PZ-II, 575-655 $\mathrm{cm}$ a.s.1.) contains fewer redeposited pollen, and consequently the concentration of primarily deposited pollen is significantly higher. The pollen assemblages indicate the dominance of tundra-like grass-sedge vegetation. Plant remains from upper part of the section are ${ }^{14} \mathrm{C}$ dated to $32,400 \pm 500 \mathrm{yr}$ B.P., corresponding to a calendar corrected age of approximately 35,000 yr B.P. (Kitagawa and van der Plicht, 2000), which agrees well with the IRSL age determination of 35,700 \pm 300 yr B.P. (Forman et al., 2002) indicating that sediments accumulated shortly after 35,000 yr B.P. Open tundra-like grass-sedge associations with few other herbs occupied the area during this time. The climate conditions in the area were more humid compared with the previous interval. 


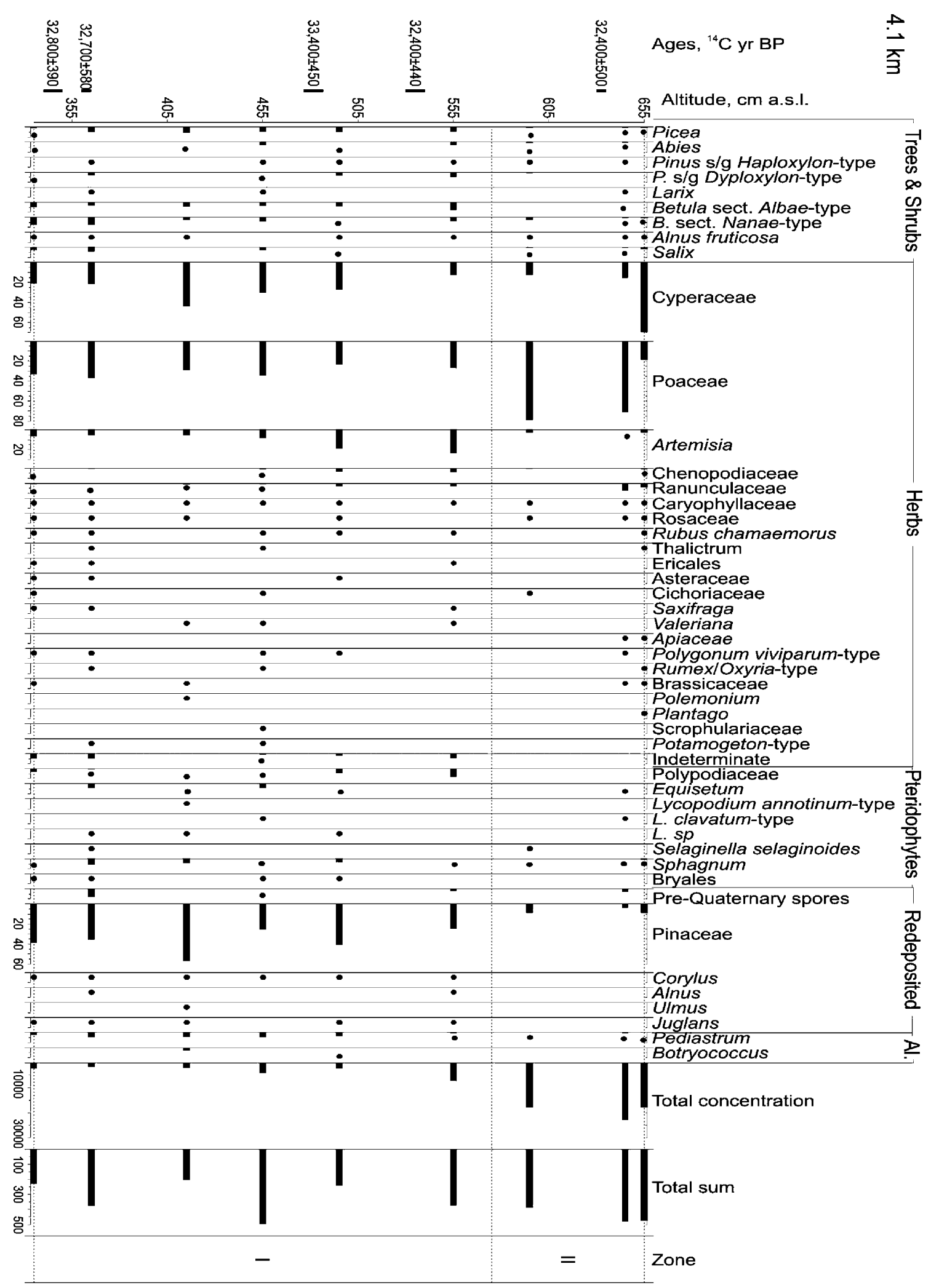

Figure 2. Percentage pollen and spore diagram of the $4.1 \mathrm{~km}$ section. •-less than $2 \%$.

The younger Karginsky records are presented in the $4.7 \mathrm{~km}$ section (Fig. 3). PZ-I (150-220 cm a.s.l.) is characterized by relatively small amounts of indeterminate reworked Pinaceae, relatively high pollen concentrations, a dominance of Poaceae and Cyperaceae pollen with relatively high amounts of
Artemisia pollen. Two radiocarbon ages of $30,100 \pm 260$ and $27,980 \pm 380{ }^{14} \mathrm{C}$ yr B.P. indicate that the sediments accumulated ca. $30,000-28,000{ }^{14} \mathrm{C}$ yr B.P. Open treeless vegetation occupied the area during this time. The climate conditions in the area were rather dry and cold. 


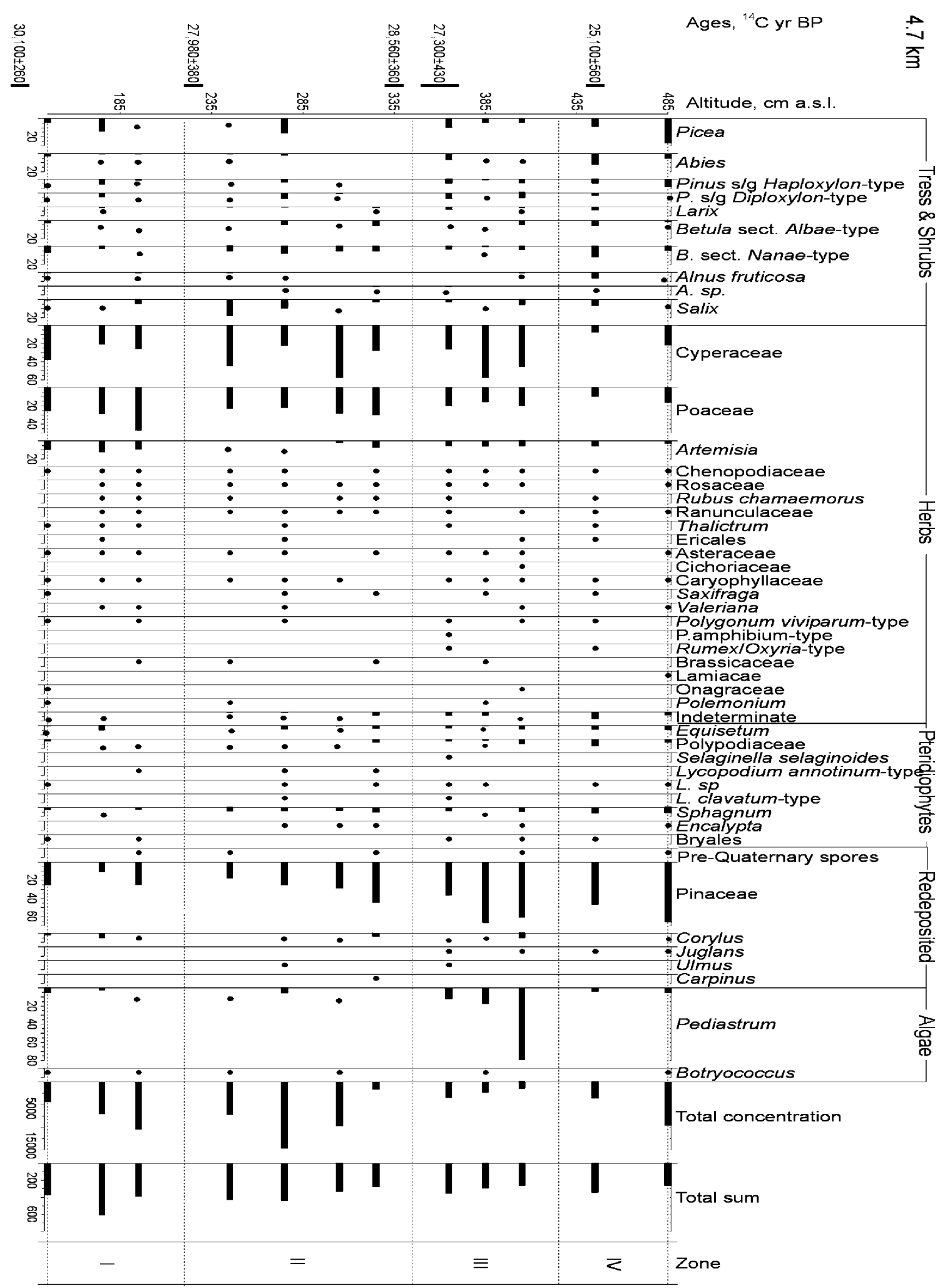

Figure 3. Percentage pollen and spore diagram of the $4.7 \mathrm{~km}$ section. •-less than $2 \%$.

PZ-II of the 4.7 section $(220-320 \mathrm{~cm}$ a.s.1.) is characterized by a slight increase of pollen concentrations. Although Poaceae and Cyperaceae pollen are dominant in the spectra, there are relatively large amounts of Betula nana and Salix pollen. Artemisia pollen almost disappeared from the spectra. Two radiocarbon dates of $27,980 \pm 380$ and $27,30 \pm 430 \mathrm{yr}$ B.P. from the 220 and $360 \mathrm{~cm}$ a.s.l., respectively, indicate that the sediments accumulated ca. $28,000-27,500{ }^{14} \mathrm{C}$ yr B.P. Pollen assemblages indicate the dominance of tundra-like vegetation and presence of shrub communities and climate amelioration in 
the area ca. $28,000-27,500{ }^{14} \mathrm{C}$ yr B.P. Similar climate amelioration has been noted on the Taymyr Peninsula (Andreev et al., 2002b, 2003) and in Lena Delta area (Andreev et al., 2002a) about this time.

The Oleny sand stratigraphic unit forms the upper part (PZIII and PZ-IV) of the 4.7 section. PZ-III (ca. $320-425 \mathrm{~cm}$ a.s.l.) is characterized by the presence of green algae colonies (Pediastrum), a decrease of pollen concentration and an increase of amounts of indeterminate reworked Pinaceae. The pollen spectra are dominated by Poaceae and Cyperaceae pollen with some Artemisia pollen. According to two radiocarbon dates, 27,300 \pm 430 and $25,100 \pm 560{ }^{14} \mathrm{C}$ yr B.P., the sediments were accumulated ca. $27,500-25,500{ }^{14} \mathrm{C}$ yr B.P. The high amounts of Pediastrum colonies and an increase of Cyperaceae pollen amounts suggest that the sedimentation occurred in wet, probably, shallow water environment. Open tundra-like and steppe-like vegetation occupied the area during this time. The climate was more severe than during the previous interval.

The sediments from the upper part of the 4.7 section (PZ-IV, Fig. 3) contain fewer Pediastrum colonies, while the total pollen concentration and amounts of redeposited Pinaceae pollen significantly increased, especially in the upper part of the zone. The pollen spectra also contain relatively large amounts of shrub and tree pollen, which are most likely reworked from the older sediments. Dominance of Poaceae and Cyperaceae pollen with relatively high amounts of Artemisia pollen indicates that tundra-like and steppe-like vegetation occupied the area around $25,000{ }^{14} \mathrm{C}$ yr B.P. The climate was drier than in the previous interval.

The so-called Baidarata Sand unit (Forman et al., 1999, 2002) overlies the Varjakha Peat and Silt and the Oleny Sand stratigraphic units. The Baidarata sediments accumulated during the Sartan (Late Weichselian) stadial contain very few palynomorphs and, therefore, were not palynologically studied.

Thus, harsh environmental conditions prevailed in the area during the late Middle Weichselian (Karginsky) time. This conclusion is in agreement with severe environments during the Karginsky interstadial reconstructed based on pollen records from Siberian regions proximal to the Arctic Ocean: coastal areas of the East-Siberian Sea (Andreev et al., 2001), Laptev Sea (Andreev et al., 2002a; Schirrmeister et al., 2003), and northern Taymyr (Andreev et al., 2003). Vasil'chuk et al. $(1984,2000)$ also reconstructs severe environmental condition on the eastern coast of Yamal Peninsula based on isotope studies of the ice wedges dated from 30,100 to $22,700{ }^{14} \mathrm{C}$ yr B.P. Consequently, it can be concluded that harsh environmental conditions prevailed in a broad region of the high Eurasian North during Middle Weichselian time.

The previously published data (e.g. Arkhipov and Volkova, 1994; Andreev et al., 2002b and references therein) inferring a warm Karginsky interstadial may have an alternative explanation. According to Astakhov (2001) the Karginsky interstadial (or even interglacial) inference is connected with misinterpretation of the so-called Karginsky sedimentary formation. Kind (1974), based on finite dates from sub-till beds with some paleontological remains indicating the climate conditions at least $3-4^{\circ}$ warmer than today, suggested a Karginsky interglacial ca $50,000-22,000$ yr ${ }^{14} \mathrm{C}$ B.P. Later, these marine strata were dated to $c a .122,000$ yr B.P. (Astakhov, 2001). We agree with Astakhov (2001) that indiscriminate use of doubtful radiocarbon dates in previous years coupled with sedimentological misinterpretation has led to the chronologic misinterpretation of Karginsky interstadial (interglacial). Our assessment places the Karginsky interstadial ca. 30,000 to $45,000{ }^{14} \mathrm{C}$ yr B.P. ago characterized by the presence of Betula nana and Salix, indicating ameliorated conditions compared to the LGM, but still harsh tundra environments prevailed on Yamal Peninsula.

\section{Acknowledgments}

This research was made possible through grants and logistical support from the Swedish Natural Sciences Research Council, the Swedish Polar Research Secretariat and the U.S. National Science Foundation (OPP-9796024). Marina Leibman (Earth Cryosphere Institute, Moscow) helped greatly with logistical preparations, and Lisa Doner (INSTAAR, University of Colorado) prepared the pollen samples. We would also like to thank two anonymous reviewers for their helpful comments for the manuscript.

\section{References}

Alexanderson, H., Hjort, Ch., Möller, P., Antonov, O., Pavlov, M., 2001. The North Taymyr ice-marginal zone, Arctic Siberia-A preliminary overview and dating. Global and Planetary Change 31, 427-445.

Andreev, A.A., Peteet, D.M., Tarasov, P.E., Romanenko, F.A., Filimonova, L.V., Sulerzhitsky, L.D., 2001. Late Pleistocene Interstadial Environment on Faddeyevskiy Island, East-Siberian Sea, Russia. Arctic. Antarctic and Alpine Research 30, 28-35.

Andreev, A.A., Schirrmeister, L., Siegert, C., Bobrov, A.A., Demske, D., Seiffert, M., Hubberten, H.-W., 2002a. Paleoenvironmental changes in northeastern Siberia during the Upper Quaternary-evidence from pollen records of the Bykovsky Peninsula. Polarforschung 70, 13-25.

Andreev, A.A., Siegert, C., Klimanov, V.A., Derevyagin, A.Yu., Shilova, G.N., Melles, M., 2002b. Late Pleistocene and Holocene vegetation and climate changes in the Taymyr lowland, Northern Siberia reconstructed from pollen records. Quaternary Research 57, 138-150.

Andreev, A.A., Tarasov, P.E., Siegert, C., Ebel, T., Klimanov, V.A., Melles, M., Bobrov, A.A., Dereviagin, A.Y., Lubinski, D., Hubberten, H.-W., 2003. Vegetation and climate changes on the northern Taymyr, Russia during the Upper Pleistocene and Holocene reconstructed from pollen records. Boreas 32, 484-505.

Andreev, A., Müller, S., Zech, W., 2004. Late Plestocene and Holocene environmental changes in Verkhoyansk Mountains. Abstracts of III International Meeting of Anthracology. Charcoals from the past. Cultural and Palaeoenvironmental implications. Covalino-Lecce (Italy). June 28thJuly 1st 2004.

Andreeva, S.M., Kind, N.V., 1982. Karginsky deposits. In: Kind, N.V., Leonov, B.N. (Eds.), Antropogen Taymyra. Nauka, Moscow. pp. 78-114 (in Russian)

Arkhipov, S.A., Volkova, V.N., 1994. Geological history, landscapes and climates of West Siberian Pleistocene. United Institute of Geology, Geophysics and Mineralogy, Novosibirsk (in Russian).

Astakhov, V.I., 2001. The stratigraphic framework for the Upper Pleistocene of the glaciated Russian Arctic: changing paradigms. Global and Planetary Change 31, 283-295.

Atlas Arktiki, 1985. Moscow, GUGK (in Russian).

Berglund, B.E., Ralska-Jasiveczowa, M., 1986. Pollen analysis and pollen 
diagrams. In: Berglund, B.E. (Ed.), Handbook of Holocene Palaeoecology and Palaeohydrology. Interscience, New York. pp. 455-484.

Cwynar, L.C., Burden, E., McAndrews, J.H., 1979. An inexpensive sieving method for concentrating pollen and spores from fine-grained sediments. Canadian Journal of Earth Sciences 16, 1115-1120.

Faegri, K., Kaland, P.E., Krzywinski, K., 1989. Textbook of Pollen Analysis, IV ed. Wiley and Sons, New York.

Forman, S.L., Ingólfsson, O., Gataullin, V., Manley, W.F., Lokrantz, H., 1999. Late Quaternary stratigraphy of western Yamal Peninsula, Russia: new constraints on the configuration of the Eurasian ice sheet. Geology 27, $807-810$.

Forman, S.L., Ingólfsson, O., Gataullin, V., Manley, W.F., Lokrantz, H., 2002. Late Quaternary stratigraphy, glacial limits, and paleoenvironments of Marresale area, western Yamal Peninsula, Russia. Quaternary Research 57, $355-370$.

Grimm, E., 1991. TILIA and TILIAGRAPH. Illinois State Museum, Springfield, Illinois.

Kitagawa, H., van der Plicht, J., 1998. Atmospheric radiocarbon calibration to 45,000 yr BP: Late glacial fluctuations and cosmogenic isotope production. Science 279, 1187-1190

Kitagawa, H., van der Plicht, J., 2000. Atmospheric radiocarbon calibration beyond $11,900 \mathrm{cal}$ BP from Lake Suigetsu laminated sediments. Radiocarbon $42,369-380$.

Mangerud, J., Astakhov, V., Svendsen, J.-I., 2002. The extent of Barents-Kara ice sheet during the Last Glacial Maximum. Quaternary Science Reviews $21,111-119$.

Möller, P., Bolshiyanov, D.Yu., Bergstein, H., 1999. Weichselian geology and paleoenvironmental history of the central Taymyr Peninsula, Siberia, indicating no glaciation during the last global glacial maximum. Boreas $28,92-114$.

Schirrmeister, L., Grosse, G., Schwamborn, G., Andreev, A., Meyer, H., Kunitsky, V.V., Kuznetsova, T., Bobrov, A., Oezen, D., 2003. Late Quaternary history of the accumulation plain north of the Chekanovsky Ridge (Lena Delta, Russia): a multidisciplinary approach. Polar Geography 27, 277-319.

Stuiver, M., Reimer, P.J., Bard, E., Beck, J.W., Burr, G.S., Hughen, K.A., Cromer, B., McCormic, G., van der Plicht, J., Spurk, M., 1998. INTCAL 98 radiocarbon age calibration, 24,000-0 cal BP. Radiocarbon 40, 1041-1083.

Vasil'chuk, Yu.K., Serova, A.K., Trofimov, V.T., 1984. New data about environmental conditions during the accumulation of Karginsky deposits. Byulleten' Komissii po izucheniyu chetvertichnogo perioda 48, 49-65 (in Russian)

Vasil'chuk, Yu.K., van der Plicht, J., Jungner, H., Vasil'chuk, A.C., 2000. AMS-dating of Late Pleistocene and Holocene syngenetic ice wedges. Nuclear Instruments and methods in Physics Research B 172, 637-641.

Volkova, V.S., 1999. Palynostratigraphy of Quaternary deposits of the Yamal and Tazovsky Peninsulas (problems of the Pliocene). Geologiya i Geofisika 40, 1119-1134 (in Russian). 